\title{
TANGGUNG JAWAB DAN KINERJA PESERTA DIDIK DALAM MENGERJAKAN PEKERJAAN RUMAH MATA PELAJARAN PENDIDIKAN KEWARGANEGARAAN DI SD MUHAMMADIYAH WIROBRAJAN II YOGYAKARTA
}

\author{
Oleh: \\ Paiman* Temu* \\ Universitas Cokroaminoto Yogyakarta
}

\begin{abstract}
Abstrak
Mata Pelajaran Pendidikan Kewarganegaraan (PKn) merupakan mata pelajaran yang memfokuskan pada pembentukan warga Negara yang memahami dan mampu melaksanakan hak-hak dan kewajibannya untuk menjadi warga Negara Indonesia yang cerdas, terampil, dan berkarakter yang diamanatkan oleh Pancasila dan Undang-Undang Dasar (UUD) 1945. Pekerjaan rumah merupakan salah satu tugas dari guru yang diberikan kepada peserta didik sebagai tugas serta salah satu cara dalam mendapatkan penilaian terhadap hasil belajar, Penelitian ini bertujuan untuk menilai tanggung jawab dan kinerja peserta didik dalam mengerjakan pekerjaan rumah pada mata pelajaran Pendidikan Kewarganegaraan di SD Muhammadiyah Wirobrajan II. Jenis penelitian ini menggunakan jenis penelitian diskriptif yaitu penelitian yang menyatakan/ menggambarkan suatu keadaan sebagaimana adanya. Data yang dikumpulkan berupa data kuantitatif (aspek kognitif), data kualitatif (aspek afektif) dan tanggung jawab pekerjaan rumah. penentuan subyek dilakukan dengan metode Proporsional Random Sampling, di mana teknik ini menggunakan perbandingan peluang yang sama bagi setiap anggota untuk dipilih menjadi anggota sampel. Subjek penelitian sebanyak 62 siswa yang tergabung dalam 3 kelas 3,4 dan 5 yang mana akan ditentukan 30 siswa secara acak. Dari 30 sampel tersebut dilakukan pengumpulan data dengan metode wawancara, observasi dan pengumpulan dokumen untuk mengetahui skor dari masing - masing sampel yang kemudian akan dilakukan analisis dari skor - skor yang telah didapat. Dari hasil penelitian diketahui masih ada beberapa siswa yang belum mengerti tanggung jawab yang diberikan oleh guru ketika siswa diberi pekerjaan rumah. Hal ini nampak dari hasil wawancara, observasi dan dokumentasi yang telah dilakukan oleh peneliti. Berdasarkan hasil trianggulasi data yang telah dilakukan dapat diketahui bahwa beberapa siswa SD Muhammadiyah Wirobrajan II sudah memiliki tanggung jawab dan memiliki kinerja yang baik dalam mengerjakan pekerjaan rumah yang diberikan oleh guru mata pelajaran PKn. Akan tetapi masih ada juga siswa yang masih memiliki tanggung jawab dan kinerja yang rendah dalam mengerjakan pekerjaan rumah.
\end{abstract}

Kata Kunci : Tanggung Jawab, Kinerja Peserta Didik. 


\section{Pendahuluan}

Pendidikan adalah usaha sadar dan terencana untuk mewujudkan suasana belajar dan proses pembelajaran agar peserta didik secara aktif mengembangkan potensi dirinya untuk memiliki kekuatan spiritual keagamaan, pengendalian diri, kepribadian, kecerdasan, akhlak mulia, serta keterampilan yang diperlukan dirinya, masyarakat, Bangsa dan Negara. Sehingga dalam melaksanakan prinsip penyelenggaraan pendidikan harus sesuai dengan tujuan pendidikan Nasional yaitu; mengembangkan kemampuan dan membentuk watak serta peradaban bangsa yang bermartabat dalam rangka mencerdaskan kehidupan bangsa, bertujuan untuk berkembangnya potensi peserta didik agar menjadi manusia yang beriman dan bertakwa kepada Tuhan Yang Maha Esa, berakhlak mulia, sehat, berilmu, cakap, kreatif, mandiri, dan menjadi warga Negara yang demokratis serta bertanggung jawab. Pembelajaran merupakan jantung dari proses pendidikan dalam suatu institusi pendidikan. Kualitas pembelajaran bersifat kompleks dan dinamis, dapat dipandang dari berbagai persepsi dan sudut pandang melintasi garis waktu.Pada tingkat mikro, pencapaian kualitas pembelajaran merupakan tanggungjawab profesional seorang guru, misalnya melalui penciptaan pengalaman belajar yang bermakna bagi siswa dan fasilitas yang didapat siswa untuk mencapai hasil belajar yang maksimal.Pada tingkat makro, melalui sistem pembelajaran yang berkualitas, lembaga pendidikan bertanggungjawab terhadap pembentukan tenaga pengajar yang berkualitas, yaitu yang dapat berkontribusi terhadap perkembangan intelektual, sikap, dan moral dari setiap individu peserta didik sebagai anggota masyarakat.

Mata Pelajaran Pendidikan Kewarganegaraan (PKn) merupakan mata pelajaran yang memfokuskan pada pembentukan warga Negara yang memahami dan mampu melaksanakan hak-hak dan kewajibannya untuk menjadi warga Negara Indonesia yang cerdas, terampil, dan berkarakter yang diamanatkan oleh Pancasila dan Undang-Undang Dasar (UUD) 1945. Perlu di ketahui dalam materi mata pelajaran PKn membahas tentang konsep nilai Pancasila dan UUD 1945 beserta dinamika perwujudan dalam kehidupan masyarakat Negara Indonesia. Sehingga mata pelajaran PKn sangat penting untuk dipelajari dan dipahami sejak dini, beranjak dari usia Sekolah Dasar (SD) agar terwujudnya nilai-nilai yang terkandung dalam PKn, diantaranya pendidikan nilai demokrasi, pendidikan nilai moral, dan pendidikan nilai sosial dalam kehidupan sehari-hari untuk menunjang kemajuan Bangsa. 
Dalam setiap pelajaran, guru akan memberikan pembelajaran dengan metode ceramah, pemberian tugas di sekolah dan pekerjaan rumah di mana peserta didik diminta untuk mengerjakan di rumah. Pekerjaan rumah yang banyak diberikan guru, masih banyak permasalahan yang dijumpai oleh peserta didik. Beberapa peserta didik masih belum memiliki tanggung jawab untuk mengerjakan tugas rumah. Siswa sering kali mengeluh ketika diberi tugas pekerjaan rumah. Tidak hanya sampai pada keluhan peserta didik, terkadang masih ada peserta didik yang mengerjakan pekerjaan rumah dengan kurang bertanggung jawab, seperti tidak menyelesaikan pekerjaan rumah mereka. Beberapa peserta didik lainnya bahkan sama sekali tidak mengerjakan pekerjaan rumah. Permasalahan mengenai pekerjaan rumah tidak hanya sampai di sini, beberapa peserta didik yang lupa atau takut mendapat hukuman atau tidak mendapat nilai, beberapa peserta didik mengerjakan pekerjaan rumah di Sekolah, peserta didik lainnya bahkan menyalin pekerjaan rumah teman untuk menghindari hukuman akibat tidak mengerjakan pekerjaan rumah. Pekerjaan rumah merupakan salah satu tugas dari guru yang diberikan kepada peserta didik sebagai tugas serta salah satu cara dalam mendapatkan penilaian terhadap hasil belajar. Selain itu, pekerjaan rumah juga dapat dijadikan sebagai salah satu penilaian terhadap kinerja peserta didik. Dengan mengetahui hasil pekerjaan rumah, guru dapat memprediksi dan mengetahui bagaimana kinerja peserta didik. Akan tetapi karena banyaknya permasalahan dan hambatan siswa dalam mengerjakan pekerjaan rumah hingga menyebabkan siswa tidak mengerjakan, mencontek dan sebagainya, menjadikan penilaian terhadap kinerja peserta didik juga ikut terganggu. Dengan berbagai permasalahan tersebut, peserta didik dinilai masih memiliki rasa tanggung jawab dan kinerja yang rendah. Oleh karena itu diperlukan penelitian mengenai tanggung jawab dan kinerja peserta didik, dalam mengerjakan pekerjaan rumah pada mata pelajaran Pendidikan Kewarganegaraan di SD Muhammadiyah Wirobrajan II. Penelitian ini diharapkan dapat mengungkap bagaimana tanggung jawab dan kinerja peserta didik dalam mengerjakan pekerjaan rumah.

\section{Kajian Teori}

Tanggung Jawab Peserta Didik, "Tanggung jawab merupakan keadaan wajib menanggung segala sesuatunya" (KBBI ; 2003: 213). Tanggung jawab juga dapat dipahami sebagai kesadaran manusia akan tingkah laku atau perbuatannya, baik yang disengaja maupun yang tidak disengaja (Sujana, 2010: 106). Rasa tanggung jawab harus dipupuk dan dibina semasa 
pertumbuhan karena setiap masa kehidupan memiliki tugas perkembangan yang berbedabeda.Tugas perkembangan yang tidak diselesaikan atau mengalami hambatan, dapat menyebabkan gangguan atau hambatan pada tugas perkembangan yang selanjutnya.Untuk itulah diperlukan perhatian khusus dari semua pihak, baik peserta didik, orang tua dan guru dalam memberikan penanaman sikap tanggung jawab terhadap anak atau peserta didik sejak dini sesuai dengan tugas perkembangan dan kemampuan anak atau peserta didik. Jenis tanggung jawab, Tanggung jawab pada diri manusia dapat dibagi dalam tiga jenis yaitu tanggung jawab pribadi, tanggung jawab kepada keluarga, tanggung jawab kepada Tuhan (Sujana, 2010: 126). Berikut penjelasan dari masing-masing jenis tanggung jawab tersebut:

1. Tanggung jawab pribadi Manusia sebagai makhluk individu memiliki pribadi yang utuh dalam berpendapat, berperasaan, berangan-angan dan bertindak apa saja. Akan tetapi, sebagai individu juga harus bertanggung jawab terhadap kewajiban yang dimiliki.

2. Tanggung jawab kepada keluarga. Keluarga merupakan inti terkecil dari kelompok masyarakat. Pengertian keluarga (inti) meliputi : ayah, ibu, anak-anak yang belum menikah. Sebagai anggota keluarga, setiap orang harus bertanggung jawab terhadap diri sendiri dan keluarga.

3. Tanggung jawab kepada Tuhan. Manusia merupakan makhluk ciptaan Tuhan, dapat mengembangkan diri sendiri dengan sarana dan prasarana pada dirinya, seperti akal, pikiran dan perasaan serta anggota tubuhnya.Semua itu atas kuasa Tuhan Yang Maha Esa, untuk itulah apapun yang dilakukan manusia akan dipertanggung jawabkan di hadapan Tuhan.

Kinerja, merupakan kegiatan yang dijalankan oleh tiap-tiap individu dalam kaitannya untuk mencapai tujuan yang sudah direncanakan. Berkaitan dengan hal tersebut terdapat beberapa definisi mengenai kinerja. Smith dalam (Mulyasa, 2005: 136) menyatakan bahwa kinerja adalah “....output drive from processes, human or otherwise”. Kinerja merupakan hasil atau keluaran dari suatu proses. Dikatakan lebih lanjut oleh Mulyasa bahwa kinerja atau performance dapat diartikan sebagai prestasi kerja, pelaksanaan kerja, pencapaian kerja, hasilhasil kerja atau unjuk kerja. Kinerja merupakan suatu konsep yang bersifat universal yang merupakan efektifitas operasional suatu organisasi, bagian organisasi, dan karyawannya berdasarkan standar dan kriteria yang telah ditetapkan sebelumnya. Karena organisasi pada dasarnya dijalankan oleh manusia maka kinerja sesungguhnya merupakan perilaku manusia 
dalam menjalankan perannya dalam suatu organisasi untuk memenuhi standar perilaku yang telah ditetapkan agar membuahkan tindakan serta hasil yang diinginkan.

Menurut Prawirasentono (1999: 2):"Performance adalah hasil kerja yang dapat dicapai oleh seseorang atau sekelompok orang dalam suatu organisasi, sesuai dengan wewenang dan tanggung jawab masing-masing, dalam rangka upaya mencapai tujuan organisasi yang bersangkutan secara legal, tidak melanggar hukum dan sesuai dengan moral ataupun etika”. Dessler (1997: 513) menyatakan pengertian kinerja hampir sama dengan prestasi kerja ialah perbandingan antara hasil kerja aktual dengan standar kerja yang ditetapkan. Dalam hal ini kinerja lebih memfokuskan pada hasil kerja. Dari beberapa pengertian tentang kinerja tersebut di atas dapat disimpulkan bahwa kinerja adalah prestasi kerja yang telah dicapai oleh seseorang. Kinerja atau prestasi kerja merupakan hasil akhir dari suatu aktifitas yang telah dilakukan seseorang untuk meraih suatu tujuan. Pencapaian hasil kerja ini juga sebagai bentuk perbandingan hasil kerja seseorang dengan standar yang telah ditetapkan. Apabila hasil kerja yang dilakukan oleh seseorang sesuai dengan standar kerja atau bahkan melebihi standar maka dapat dikatakan kinerja itu mencapai prestasi yang baik. Kinerja yang dimaksudkan diharapkan memiliki atau menghasilkan mutu yang baik dan tetap melihat jumlah yang akan diraihnya. Suatu pekerjaan harus dapat dilihat secara mutu terpenuhi maupun dari segi jumlah yang akan diraih dapat sesuai dengan yang direncanakan. Peserta Didik, Menurut pasal 1 ayat 4 UU RI No. 20 Tahun 2003 tentang sistem Pendidikan Nasional, peserta didik adalah anggota masyarakat yang berusaha mengembangkan dirinya melalui proses pendidikan pada jalur jenjang dan jenis pendidikan tertentu.

Abu Ahmadi (2001: 40) juga menuliskan tentang pengertian peserta didik, peserta didik adalah orang yang belum dewasa, yang memerlukan usaha, bantuan, bimbingan orang lain untuk menjadi dewasa, guna dapat melaksanakan tugasnya sebagai makhluk Tuhan, sebagai umat manusia, sebagai warga Negara, sebagai anggota masyarakat dan sebagai suatu pribadi atau individu. Dari definisi yang diungkapkan para ahli di atas dapat disimpulkan bahwa peserta didik adalah orang yang mempunyai fitrah (potensi) dasar, baik secara fisik maupun psikis, yang perlu dikembangkan, untuk mengembangkan potensi tersebut sangat membutuhkan pendidikan dari pendidik. Peserta didik mempunyai kewajiban, diantaranya yaitu menurut UU RI No. 20 th 2003: 
a. Menjaga norma-norma pendidikan untuk menjamin keberlangsungan proses dan keberhasilan pendidikan.

b. Ikut menanggung biaya pendidikan kecuali bagi yang dibebaskan dari kewajiban tersebut.

Menurut Asma Hasan Fahmi, sebagai mana yang dikutip oleh Samsul Nizar (2002: 47), menuliskan beberapa kewajiban peserta didik antara lain :

a. Peserta didik hendaknya membersihkan hatinya sebelum menuntut ilmu, hal ini disebabkan karena menuntut ilmu adalah ibadah dan tidak sah ibadah kecuali dengan hati yang bersih.

b. Tujuan belajar hendaknya ditujukan untuk menghiasi ruh dengan berbagai sifat keutamaan.

c. Memiliki kemampuan yang kuat untuk mencari dan menuntut ilmu di berbagai tempat.

d. Setiap peserta didik wajib menghormati pendidiknya.

e. Peserta didik hendaknya belajar secara sungguh-sungguh dan tabah dalam belajar.

Kinerja Peserta Didik, Berdasarkan pengertian kinerja dan peserta didik tersebut, dapat diketahui bahwa kinerja peserta didik adalah prestasi kerja yang telah dicapai oleh peserta didik dalam mencapai tujuan yang diharapkan. Dengan demikian maka dapat diketahui bagaimana hasil belajar atau prestasi peserta didik dalam mata pelajaran Pendidikan Kewarganegaraan. Mata Pelajaran Pendidikan Kewarganegaraan, depdiknas (2006: 49) memberikan penjelasan bahwa Pendidikan Kewarganegaraan adalah mata pelajaran yang memfokuskan pada pembentukan Warga Negara yang memahami dan mampu melaksanakan hak-hak dan kewajibannya untuk menjadi Warga Negara Indonesia yang cerdas, terampil, berkarakter yang diamanatkan oleh Pancasila dan UUD 1945.

Sedangkan Sumantri (2001: 154) memberikan perumusan pengertian Pendidikan Kewarganegaraan sebagai berikut: PKn merupakan usaha untuk membekali peserta didik dengan pengetahuan dan kemampuan dasar yang berkenaan dengan hubungan antara Warga Negara dengan negara serta pendidikan pendahuluan bela negara agar menjadi Warga Negara agar dapat diandalkan oleh Bangsa dan Negara. Berdasarkan kedua pengertian di atas jelas bahwa PKn merupakan mata pelajaran yang memiliki fokus pada pembinaan karakter warga Negara dalam perspektif kenegaraan, diharapkan melalui mata pelajaran ini dapat terbina sosok Warga Negara yang baik (good citizenship). Sejalan dengan Pengertian Pendidikan Kewarganegaraan menurut Peraturan Menteri Pendidikan Nasional Nomor 22 Tahun 2006 tentang Standar Isi untuk Satuan Pendidikan Dasar dan Menengah adalah mata pelajaran yang memfokuskan pada pembentukan Warga Negara yang memahami dan mampu melaksanakan hak-hak dan kewajibannya untuk 
menjadi Warga Negara Indonesia yang cerdas, terampil, dan berkarakter yang diamanatkan oleh Pancasila dan UUD 1945. Kemudian menurut Azis Wahab (Cholisin, 2000: 18) menyatakan bahwa PKn ialah media pengajaran yang meng-Indonesiakan para peserta didik secara sadar, cerdas, dan penuh tanggung jawab. Karena itu, program PKn memuat konsep-konsep umum ketatanegaraan, politik dan hukum Negara, serta teori umum yang lain yang cocok dengan target tersebut. Berbeda dengan pendapat di atas Pendidikan Kewarganegaraan diartikan sebagai penyiapan generasi muda (peserta didik) untuk menjadi Warga Negara yang memiliki pengetahuan, kecakapan, dan nilai-nilai yang diperlukan untuk berpartisipasi aktif dalam masyarakatnya (Samsuri, 2011: 28). Berdasarkan beberapa pendapat tersebut dapat dikemukakan bahwa Pendidikan Kewarganegaraan adalah suatu mata pelajaran yang merupakan satu rangkaian proses untuk mengarahkan peserta didik menjadi Warga Negara yang berkarakter Bangsa Indonesia, cerdas, terampil, dan bertanggung jawab sehingga dapat berperan aktif dalam masyarakat sesuai dengan ketentuan Pancasila dan UUD 1945.

Tujuan Pendidikan Kewarganegaraan, adalah untuk membentuk watak atau karakteristik Warga Negara yang baik. Sedangkan tujuan pembelajaran mata pelajaran PKn, menurut Mulyasa (2007) adalah untuk menjadikan peserta didik:

a. Mampu berpikir secara kritis, rasional, dan kreatif dalam menanggapi persoalan hidup maupun isu Kewarganegaraan di Negaranya.

b. Mau berpartisipasi dalam segala bidang kegiatan, secara aktif dan bertanggung jawab, sehingga bisa bertindak secara cerdas dalam semua kegiatan, dan

c. Bisa berkembang secara positif dan demokratis, sehingga mampu hidup bersama dengan bangsa lain di dunia dan mampu berinteraksi, serta mampu memanfaatkan teknologi informasi dan komunikasi dengan baik.

Tujuan Pendidikan Kewarganegaraan diatur dalam Permendiknas Nomor 22 Tahun 2006 tentang Standar Isi untuk Satuan Pendidikan Dasar dan Menengah. Tujuannya adalah agar peserta didik memiliki kemampuan sebagai berikut:

a. Berpikir secara kritis, rasional dan kreatif dalam menanggapi isu Kewarganegaraan.

b. Berpartisipasi secara aktif dan bertanggung jawab, dan bertindak secara cerdas dalam kegiatan bermasyarakat, berbangsa dan bernegara, serta anti-korupsi.

c. Berkembang secara positif dan demokratis untuk membentuk diri berdasarkan karakterkarakter masyarakat Indonesia agar dapat hidup bersama dengan Bangsa lain. 
d. Berinteraksi dengan masyarakat Bangsa lain dalam percaturan dunia secara langsung atau tidak langsung dengan memanfaatkan teknologi informasi dan komunikasi.

Ahmad Sanusi (dalam Cholisin, 2004: 15) menyebutkan bahwa konsep-konsep pokok yang lazimnya merupakan tujuan Civic Education pada umumnya adalah sebagai berikut:

a. Kehidupan di dalam jaminan konstitusi.

b. Pembinaan bangsa menurut syarat konstitusi.

c. Kesadaran Warga Negara akan pendidikan dan komunikasi politik.

d. Pendidikan untuk (ke arah) Warga Negara yang bertanggung jawab.

e. Latihan berdemokrasi.

f. Turut serta secara aktif dalam urusan publik.

g. Sekolah sebagai laboratoriun demokrasi.

h. Prosedur dalam pengambilan keputusan.

i. Latihan kepemimpinan.

j. Pengawasan demokrasi terhadap lembaga eksekutif dan legislatif.

k. Menumbuhkan pengertian dan kerjasama Internasional.

Dari tujuan yang dikemukakan oleh beberapa ahli di atas, diketahui bahwa tujuan Pendidikan Kewarganegaraan memuat beberapa hal yang memuat nilai-nilai karakter.Untuk mencapai tujuan tersebut Pendidikan Kewarganegaraan memiliki komponen-komponen yaitu pengetahuan Kewarganegaraan (civic knowledge), keterampilan Kewarganegaraan (civic skill), dan karakter Kewarganegaraan (civic disposition) yang masing-masing memiliki unsur. Berdasarkan pemaparan di atas dapat dikemukakan tujuan Pendidikan Kewaranegaran dapat diartikan sebagai mata pelajaran yang fokus pada pembentukan Warga Negara yang memiliki keterampilan intelektual, ketrampilan berpartisipasi dalam setiap kegiatan Kewarganegaraan dan memiliki karakter kewarganegaraan yang kuat sehingga menjadikan Warga Negara yang cerdas dan berkarakter. Ruang Lingkup Pendidikan Kewarganegaraan, diatur dalam Permendiknas No. 22 tahun 2006 tentang Standar Isi untuk Satuan Pendidikan Dasar dan Menengah. Ruang lingkup mata pelajaran PKn untuk pendidikan dasar dan menengah secara umum meliputi aspekaspek sebagai berikut:

a. Persatuan dan Kesatuan Bangsa, meliputi hidup rukun dalam perbedaan, cinta lingkungan, kebanggaan sebagai Bangsa Indonesia, sumpah pemuda, keutuhan Negara Kesatuan 
Republik Indonesia, partisipasi dalam pembelaan Negara, sikap positif terhadap Negara Kesatuan Republik Indonesia, keterbukaan dan jaminan keadilan.

b. Norma, hukum dan peraturan, meliputi tertib dalam kehidupan keluarga, tata tertib di sekolah, norma yang berlaku di masyarakat, peraturan-peraturan daerah, norma-norma dalam kehidupan Berbangsa dan Bernegara, sistem hukum dan peradilan Nasional, hukum dan peradilan Internasional.

c. Hak Asasi Manusia, meliputi hak dan kewajiban anak, hak dan Kewajiban anggota masyarakat, instrumen Nasional dan Internasional HAM, pemajuan penghormatan dan perlindungan HAM.

d. Kebutuhan Warga Negara, meliputi hidup gotong royong, harga diri sebagai masyarakat, kebebasan berorganisasi, kemerdekaan mengeluarkan pendapat, menghargai keputusan bersama, prestasi diri, persamaan kedudukan warga negara.

e. Konstitusi Negara, meliputi proklamasi kemerdekaan dan konstitusi yang pertama, konstitusi-konstitusi yang pernah digunakan di Indonesia, hubungan Dasar Negara dengan Konstitusi.

f. Kekuasaan dan politik, meliputi pemerintahan desa dan kecamatan, pemerintahan daerah dan otonomi, pemerintah pusat, demokrasi dan sistem politik, budaya politik, budaya demokrasi menuju masyarakat madani, sistem pemerintahan, pers dalam masyarakat demokrasi.

g. Pancasila, meliputi, kedudukan pancasila sebagai Dasar Negara dan ideologi negara, proses perumusan pancasila sebagai Dasar Negara, pengamalan nilai-nilai pancasila dalam kehidupan sehari-hari, pancasila sebagai ideologi terbuka.

h. Globalisasi, meliputi: globalisasi di lingkungannya, politik luar negeri Indonesia di era globalisasi, dampak globalisasi, hubungan internasional dan organisasi internasional, dan mengevaluasi globalisasi.

Berdasarkan ruang lingkup PKn di atas, diketahui bahwa materi yang ada dalam PKn terdiri dari diantaranya tentang materi nilai-nilai, norma dan peraturan hukum yang mengatur perilaku Warga Negara, sehingga diharapkan peserta didik dapat mengamalkan materi tersebut dalam kehidupan sehari-hari menjadi karakter pribadi yang melekat pada setiap individu peserta didik. Atau dapat juga diketahui bahwa Ruang Lingkup Pendidikan Kewarganegaraan (PKn). Berdasarkan tujuan tersebut diatas, maka materi dalam pembelajaran PKn perlu diperjelas. Oleh 
karena itu, ruang lingkup PKn secara umum meliputi aspek-aspek sebagai berikut. (1) Persatuan dan Kesatuan, (2) Norma Hukum dan Peraturan, (3) HAM, (4) Kebutuhan Warga Negara, (5) Konstitusi Negara, (6) Kekuasaan Politik, (7) Kedudukan Pancasila, dan (8) Globalisasi.

Peran, Kedudukan dan Fungsi Guru, dalam Undang-Undang nomor 20 tahun 2003 tentang Sistem Pendidikan Nasional Pasal 1, mengenai ketentuan umum butir 6, pendidik adalah tenaga kependidikan yang berkualifikasi sebagai guru, dosen, konselor, pamong belajar, widya iswara, tutor, instruktur, fasilitator, dan sebutan lain yang sesuai dengan kekhususannya, serta berpartisipasi dalam menyelenggarakan pendidikan. Dengan kata lain, dapat dikatakan bahwa guru adalah pendidik. Menurut Kamus Besar Bahasa Indonesia (2005: 377), yang dimaksud dengan guru adalah orang yang pekerjaannya (mata pencahariannya, profesinya) mengajar. Pengertian guru menurut KBBI di atas, masih sangat umum dan belum bisa menggambarkan sosok guru yang sebenarnya, sehingga untuk memperjelas gambaran tentang seorang guru diperlukan definisi-definisi lain.

Suparlan dalam bukunya yang berjudul -Menjadi Guru Efektif, mengungkapkan hal yang berbeda tentang pengertian guru. Menurut Suparlan (2008: 12), guru dapat diartikan sebagai orang yang tugasnya terkait dengan upaya mencerdaskan kehidupan bangsa dalam semua aspeknya, baik spiritual dan emosional, intelektual, fisikal, maupun aspek lainnya. Secara legal formal, guru adalah seseorang yang memperoleh surat keputusan (SK), baik dari pemerintah maupun pihak swasta untuk mengajar. Proses Pembelajaran Pendidikan Kewarganegaraan Mengenai Tanggung Jawab dan Kinerja Peserta Didik, terjadinya belajar seseorang karena dipengaruhi faktor dari luar dan faktor dari dalam diri orang tersebut,keduanya saling berinteraksi. Faktor dari luar (eksternal) yaitu stimulus dan lingkungan dalam kegiatan belajar, dan faktor dari dalam (internal) yaitu faktor yang menggambarkan keadaan proses kognitif peserta didik. Keadaan internal menunjukkan pengetahuan dasar (yang berhubungan dengan bahan ajar), sedangkan proses kognitif menunjukkan bagaimana kemampuan siswa mengolah bahan ajar yang diterima. Menurut Gagne (dalam Purwanto, 2011: 3) tanggung jawab peserta didik adalah berbagai kemampuan yang diperoleh dari proses belajar. Ada 5 (lima) jenis kemampuan peserta didik, diantaranya adalah keterampilan intelektual, informasi verbal, strategi kognitif, keterampilan motorik dan sikap. 
Belajar, memiliki beberapa tahapan, diantaranya adalah sebagai berikut:

a. Persiapan untuk belajar dengan melakukan tindakan pengarahan perhatian, pengharapan, dan mendapatkan kembali informasi.

b. Pemerolehan dan unjuk perbuatan yang digunakan untuk persepsi selektif, sandi semantik, pembangkitan kembali, respon dan pengetahuan.

c. Alih belajar yaitu pengisyaratan untuk membangkitkan dan memberlakukan secara umum.

Menurut Gagne (dalam Sumarno, 2011) hasil belajar merupakan hasil interaksi stimulus dari luar dengan pengetahuan internal siswa. Teori belajar sebagaimana dikemukakan di atas dapat digunakan sebagai dasar dalam penanaman sikap tanggung jawab dalam proses pembelajaran.

\section{Pembahasan}

Tanggung jawab dan kinerja mengerjakan pekerjaan rumah dalam bidang kognitif, berdasarkan hasil penelitian terungkap bahwa tanggungjawab dan kinerja siswa dalam mengerjakan pekerjaan rumah dilakukan pada tiga bidang, yaitu kognitif, afektif, dan psikomotorik. Pada bidang kognitif tanggungjawab dan kinerja siswa dalam mengerjakan pekerjaan rumah tercermin pada kesediaan siswa mengerjakan pekerjaan rumah dan kesediaan siswa untuk mengerjakan pekerjaan rumah dengan sebaik-baiknya. Berdasarkan hasil observasi terungkap bahwa ada beberapa siswa yang masih belum mengerjakan pekerjaan rumah, beberapa diantaranya mengerjakan pekerjaan rumah mereka disekolah, ada pula siswa yang mengerjakan pekerjaan rumah dengan mencontek hasil pekerjaan temannya. Berdasarkan hasil wawancara diketahui bahwa hasil observasi yang dilakukan diakui secara jujur oleh siswa. Diantaranya beberapa siswa mengakui bahwa mereka pernah tidak mengerjakan pekerjaan rumah mereka, pernah mengerjakan pekerjaan rumah di sekolah dan pernah mencontek pekerjaan rumah milik teman.

Tidak jauh berbeda dengan hasil observasi dan wawancara yang dilakukan, hasil olah dokumen juga menunjukkan bahwa masih ada beberapa siswa yang tidak mendapat nilai memuaskan walau pekerjaan itu adalah pekerjaan rumah. Pekerjaan atau tugas yang dapat dikerjakan siswa bersama-sama dengan orang tua atau setidaknya mereka dapat melihat buku panduan atau buku paket serta catatan ketika mereka berada di sekolah.

Tanggung jawab dan kinerja mengerjakan pekerjaan rumah dalam bidang afektif, selain pada bidang kognitif tanggungjawab dan kinerja siswa dalam mengerjakan pekerjaan 
rumah juga terdapat pada bidang afektif. Untuk itu peneliti berupaya mendapatkan informasi tentang perasaan siswa ketika menerima pekerjaan rumah dan perasaan siswa ketika tidak mengerjakan pekerjaan rumah.

Berdasarkan hasil observasi diketahui bahwa siswa ada beberapa siswa yang masih memiliki ketakutan untuk mengutarakan pendapat, selain itu juga ketika ada pembahasan pekerjan rumah di sekolah, ada beberapa siswa yang masih malu-malu. Akan tetapi tidak sedikit juga yang telah dapat mengutarakan pendapat atau setidaknya menyampaikan pertanyaan ketika mereka tidak memahami pembahasan yang telah dilakukan. Berdasarkan hasil wawancara yang telah dilakukan, menunjukkan hasil yang tidak jauh berbeda dengan hasil observasi. Beberapa siswa mengakui bahwa masih merasa enggan untuk dapat mengutarakan pendapat atau menanyakan hal-hal yang masih belum mereka mengerti. Akan tetapi tidak sedikit pula diantara mereka yang telah mulai berani bertanya dan menjawab pertanyaan guru.

Hasil dokumentasi menunjukkan bahwa dalam beberapa kali pekerjaan rumah ada beberapa siswa yang nilainya tidak meningkat bahkan menurun, hal ini dapat diindikasikan ketika mereka tidak mau bertanya terhadap guru, maka sebenarnya mereka belum memahami materi atau pekerjaan rumah yang mereka kerjakan.

Tanggung jawab dan kinerja mengerjakan pekerjaan rumah dalam bidang psikomotorik, selain pada bidang kognitif dan afektif, Tanggung jawab dan kinerja siswa dalam mengerjakan pekerjaan rumah juga dalam bidang psikomotorik. Karena itu peneliti berupaya mendapatkan informasi tentang tanggungjawab dan kinerja siswa dalam menghadapi persoalan yang belum terselesaikan serta bagaimana siswa bersikap ketika tidak mengerjakan pekerjaan rumah. Berdasarkan hasil observasi diketahui beberapa siswa sudah mulai berani maju ke depan kelas untuk menunjukkan hasil pekerjaan rumahnya, selain itu juga memiliki semangat ketika melakukan pembahasan pekerjaan rumah. Akan tetapi masih ada pula siswa yang merasa malu dan takut ketika akan melakukan pembahasan pekerjaan rumah walaupun mereka telah mengerjakan pekerjaan rumah mereka, ada pula yang takut karena sama sekali belum mengerjakan pekerjaan rumah. Hasil wawancara menunjukkan hal yang tidak jauh berbeda dengan hasil observasi di mana beberapa siswa mengakui bahwa ketika beberapa siswa tidak mengerjakan pekerjaan rumah, maka ketika melakukan pembahasan mereka merasa tidak antusias dan cenderung takut karena belum mengerjakan pekerjaan rumah yang seharusnya. 


\section{Kesimpulan}

Berdasarkan penelitian yang telah dilakukan dapat diperoleh kesimpulan sebagai berikut:

1. Siswa kelas III termasuk dalam kategori siswa yang memiliki tanggung jawab dan kinerja yang sedang dalam mengerjakan pekerjaan rumah, hal ini nampak dalam hasil penelitian di mana $45 \%$ siswa (5 orang) memiliki tanggung jawab dan kinerja tinggi, sedangkan 55\% siswa (6 orang) memiliki tanggug jawab dan kinerja sedang.

2. Siswa kelas IV termasuk dalam kategori siswa yang memiliki tanggung jawab dan kinerja yang sedang dimana 30\% siswa (3 orang) memiliki tanggung jawab dan kinerja dengan kategori tinggi, sedangkan $70 \%$ siswa (7 orang) memiliki tanggung jawab dan kinerja sedang dalam mengerjakan pekerjaan rumah.

3. Siswa kelas $\mathrm{V}$ termasuk dalam kategori siswa yang memiliki tanggung jawab dan kinerja tinggi, hal ini nampak bahwa $78 \%$ siswa (7 orang) memiliki tanggung jawab dan kinerja tinggi, sedangkan $22 \%$ siswa(2 orang) memiliki tanggung jawab dan kinerja tinggi sedang.

4. Tanggung jawab, kinerja dalam bidang kognitif, kinerja dalam bidang afektif dan kinerja dalam bidang psikomotorik memiliki hubungan yang erat dan berbanding lurus, jika tanggung jawab tinggi, maka kinerja dalam bidang kognitif, afektif dan psikomotorik juga akan tinggi. Hasil penelitian yang telah dilakukan menunjukkan bahwa subyek memiliki tanggung jawab yang tinggi sebesar 63\%, kinerja bidang kognitif menunjukkan tinggi sebesar 60\%, kinerja dalam bidang afektif menunjukkan $70 \%$ dan kinerja bidang psikomotorik menunjukkan 53\%.

\section{Daftar Pustaka}

Abdullah. 2005. Sikap dan perilaku, Jakarta: Rineka Cipta.

Abu Ahmadi dan Nur Uhbiyati. 2001. Ilmu Pendidikan, Jakarta: PT. Rineka Cipta

Azwar, Syaiffudin. 2007. Sikap Manusia, Teori Dan Pengukuran. Yogyakarta: Pustaka Pelajar

Departemen Pendidikan Nasional.2006. Standar Kompetensi dan Kompetensi Dasar, Jakarta: Mendiknas

Depdiknas, Pusat Bahasa.2002. Kamus Besar Bahasa Indonesia. Jakarta: Balai Bahasa 
Purwanto,Ngalim.2011.Psikologi Pendidikan.Bandung:PT.Remaja Rosdakarya

Samsul, Nizar. 2002. Filsafat Pendidikan Islam. Jakarta: Ciputat press.

Sarwono, Sarlito. 2002. Psikologi Sosial. Jakarta: Balai Pustaka

Sugiyono. 2009. Metode Penelitian Kuantitatif Kualitatif dan $R \& D$. Bandung : Alfabet.

Suharsimi, Arikunto. 2002. Metodologi Penelitian, Jakarta: PT. Rineka Cipta

Suryabrata, Sumadi. 2008. Metode Penelitian. Jakarta: Raja Grafindo Persada

UU No. 20 Tahun 2003 Tentang Sistem Pendidikan Nasional

UU No. 14 Tahun 2005 Tentang Guru dan Dosen 